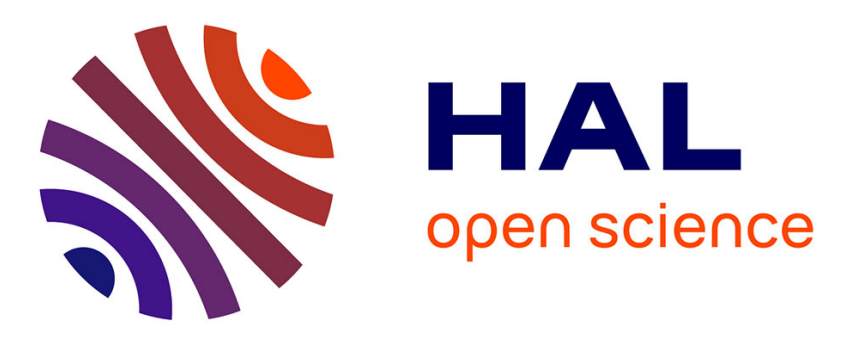

\title{
Virtual fracture reduction of the acetabulum using a rigid body biomechanical model
}

Mehdi Boudissa, Matthieu Chabanas, Hadrien Oliveri, Jérôme J. Tonetti

\section{To cite this version:}

Mehdi Boudissa, Matthieu Chabanas, Hadrien Oliveri, Jérôme J. Tonetti. Virtual fracture reduction of the acetabulum using a rigid body biomechanical model. 90e Réunion annuelle de la SOFCOT, 2015, Paris, France. pp.S187, 10.1016/j.rcot.2015.09.119 . hal-01233931

\section{HAL Id: hal-01233931 \\ https://hal.science/hal-01233931}

Submitted on 4 Jan 2017

HAL is a multi-disciplinary open access archive for the deposit and dissemination of scientific research documents, whether they are published or not. The documents may come from teaching and research institutions in France or abroad, or from public or private research centers.
L'archive ouverte pluridisciplinaire HAL, est destinée au dépôt et à la diffusion de documents scientifiques de niveau recherche, publiés ou non, émanant des établissements d'enseignement et de recherche français ou étrangers, des laboratoires publics ou privés. 


\title{
Virtual fracture reduction of the acetabulum using a rigid body biomechanical model
}

\author{
Mehdi Boudissa *, Matthieu Chabanas, Hadrien Oliveri, Jérôme Tonetti \\ CHU Grenoble Alpes, Univ Grenoble Alpes, Boulevard de la Chantourne 38700 La Tronche \\ * Corresponding author. \\ E-mail address: mboudissa@chu-grenoble.fr (M. Boudissa)
}

\section{Introduction}

About computer-assisted surgery in acetabular fractures, several preoperative planning tools have been proposed to simulate the desired reduction based on geometrical constraints. The main contribution of this work is an intuitive simulation of the surgical procedure itself, to evaluate different strategies until the best reduction is achieved.

\section{Material and methods}

3D model of the hip bones, including separated fragments, is first build out of the CT images using an existing non-commercial software (itksnapy), to perform automatic threshold, region growing with active contours and finally manual refinements. Models of adequate quality, similar to other authors, could be built in less than 30 minutes in complex cases. To simulate the surgical procedure we have chosen to use a mechanical model of the hip joint bony elements, implemented within the non-commercial Artisynthy framework. Each bone fragment is considered as an independent rigid body. One of them is usually considered as fixed, e.g. the anterior or posterior column and or the femoral head. Collisions are handled to ensure non-penetration between elements, with dry friction (Coulomb) response. The action of a clamp is simulated via a Hill muscle model which extremities are the clamp jaws positions on the bones. The interactive "contraction" of this model applies forces similarly to the real clamp action.

Results

The position of the clamps is chosen by the surgeon according to his knowledge of the surgical approach and the feasibility of the procedure. The surgeon tries to reproduce, in the other way, the initial displacement to get a perfect reduction. The best reduction is obtained when the less of manipulations are made. We have simulated several ways of reduction and the best procedure is presented here in a clinical case with a transverse + posterior wall fracture of the acetabulum.

\section{Conclusion}

A new method has been proposed for virtual fracture reduction. Unlike unconstrained geometrical repositioning, the biomechanical model enables to easily and intuitively simulate the effects of real surgical procedures. Even if limits could be addressed, especially the soft tissue environment of the hip area, preliminary results are quite promising. This technique could be an effective planning tool for the surgeon to define his best therapeutic strategy, mostly which surgical access to choose as well as how and in which order to reposition the bone fragments.

\section{Disclosure of interest}

The authors declare that they have no conflicts of interest concerning this article.

http://dx.doi.org/10.1016/j.rcot.2015.09.119

Virtual fracture reduction of the acetabulum using a rigid body biomechanical model Revue de Chirurgie Orthopédique et Traumatologique, Volume 101, Issue 7, Page S187 Mehdi Boudissa, Matthieu Chabanas, Hadrien Oliveri, Jérôme Tonetti 